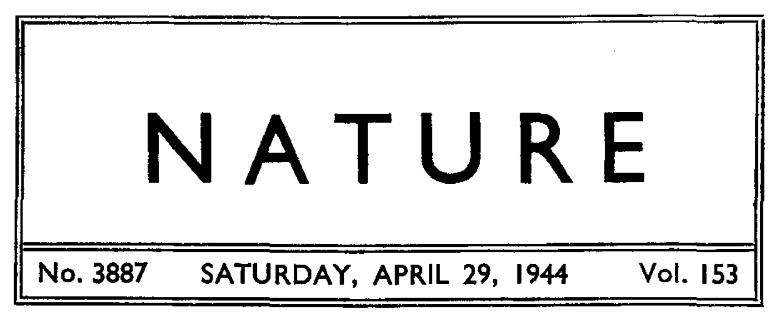

CONTENTS

Location of Industry and Provision of Man-power

Page

Judgment on Planning. By R. Brightman

Fat Metabolism. By Dr. A. Kleinzeller . . . 510

Electronic Theory in Chemistry. By Prof. E. D. Hughes 510

Neolithic Forest Clearance. By Dr. H. Godwin . 511

Ancient Astrology. By Joshua C. Gregory . . 512

Pre-Neanderthal Man in the Crimea. By Sir Arthur Keith, F.R.S

Obituaries :

Prof. L. R. Wilberforce. By Dr. R. W. Roberts 517

Sir Thomas Ranken Lyle, F.R.S. By Dr. J. I. O.

Masson, M.B.E., F.R.S.

Mr. S. E. Winbolt. By I. D. Margary . . 518

Prof. L. S. Palmer . . . . . . . 518

News and Views . $. \quad . \quad . \quad . \quad . \quad . \quad 519$

Letters to the Editors:

The Osmotic Balance.-Ingvar Jullander and Prof. The Svedberg

Organic and Inorganic Pyrophosphates as Shockinducing Agents.-Marian Bielschowsky and Prof. H. N. Green

Reaction between Proteins and Formaldehyde.Dr. R. L. Wormell and Maurice A. G. Kaye .

Methionine in the Treatment of Liver Damage.Prof. J. Beattie and Major J. Marshall

Effect of Vitamin $C$ on the Adrenaline Content of the Adrenal Glands of Guinea Pigs.-Sachchidananda Banerjee

White Plumage of Sea-Birds.-Dr. M. H. Pirenne and Dr. A. C. Crombie ; Dr. K. J. W. Craik ; Edward A. Armstrong

Immediate Effect of X-Rays on the Movements of Larva and Pupz of Mosquitoes.-G. Goldhaber and B. Feldman-Muhsam

Cultures of Excised Leguminous Roots.-Moira P. McGonagle

Absorption in the Atmosphere and Decay of Cosmic Rays.-Prof. A. Duperier. . .

Roozeboom's Type II of Solid Solution.-Prof.

A. N. Campbell

Research Items

$X$-Ray Analysis in Industry : Conference of the X-Ray

Analysis Group of the Institute of Physics.

Reform of School Mathematical Syllabuses . . 535

Control of Typhus. By Dr. G. Lapage . . . . 536

Recent Scientific and Technical Books . . Supp. ii

\footnotetext{
Editoriol and Publishing Offices

Editorial and Publishing Offices

MACMILLAN \& CO., LTD.,

ST. MARTIN'S STREET, LONDON, W.C.2.

Telephone Number: Whitehall 8831

Telegrams: Phusis Lesquare London

Advertisements should be addressed to

T. G. Scott \& Son, Led., Talbot House, 9 Arundel Street, London, W.C.2

Telephone : Temple Bar 1942

The annual subscription rate is $\$ 4100$, payable in advance, Inland or Abroad. The annual subscription rate is $\notin 4100$, payable in advance, Inland or Abroad.
Alt rights reserved. Registered as a Newspaper at the General Post Office
}

\section{LOCATION OF INDUSTRY AND PROVISION OF MAN-POWER}

$T$

HE memorandum, "Considerations Affecting Post-War Employment in the North-East", which has been issued by the Northern Industrial Group, consisting of employers and trade-union leaders in northern England, and which has been sent to the Minister of Reconstruction, is not only of interest in relation to post-war reconstruction and employment policy and the change from a war to a peace economy. It may well be compared with the report submitted in May 1935 to the District Commissioner for Depressed Areas by a joint committee of the local sections of the Society of Chemical Industry, the Royal Institute of Chemistry and the Chemical Society, and with a subsequent report, "The Industrial Position of the North-East Coast of England", issued later in the same year by the staff of the Economics Depart. ment of Armstrong College, Newcastle on Tyne. The conclusions reached in the latter report appear to be fully confirmed and to be as valid to-day as eight years ago, and substantially the same is true of the other report and especially of the section contributed by the sub-committee on science and industry.

The Northern Industrial Group in its memorandum points out that the War has brought no real change to the industrial structure in the area. That structure remains much as it was in the days of the depression; and unless adequate preventive measures are taken there is real danger that the employment and standard of living of people in the area will again be seriously threatened after the present War. Still more disturbing, not to say disappointing, is the absence in this memorandum of any real evidence that the lessons set forth so clearly in the reports from Armstrong College and the joint committee of the chemical societies have been learnt, or of the extensive application of scientific methods to those industries which situation and local raw materials make possible. Something more than vigorous action on the part of the central Government still appears to be required to eliminate the threat of large-scale unemployment in the area ; and while responsibility for the position cannot fairly be laid entirely on the industrial leaders of the area, they have yet to clear themselves of the charge of absence of foresight and neglect of science brought against them eight years ago.

There are other respects in which the general situation has changed; but the indictment in the earlier reports needs to be kept in mind the more because of the shift in emphasis from local to national responsibility, which has been accentuated in the interval. It is now widely recognized, and rightly, that certain basic decisions as to policy must be made by the central Government before local authorities or even regional authorities can act wisely or effectively. The memorandum of the Northern Industrial Group assumes first, for example, that a national economic policy will be adopted, and that to secure ample employment in reparation and reconstruction work at home and abroad the Government 
will continue to control production in some way for an interim period of unknown length after the War, with a gradual change to a peace-time economy. In this interim period, any deficiencies in employment in Great Britain should be met by work on the many necessary schemes for public works. National policy should also assure a stable level of employment in the heavy industries and in agriculture.

Even with such measures, on the basis of the immediate pre-war industrial structure of the region, there will be a surplus of some 130,000 persons for whom employment will have to be found, and such estimates of the post-war capacity of the heavy industries in the area as the Group is able to make suggest that new forms of occupation will be required for more than 100,000 people, even without allowing for women seeking employment. The Group, however, firmly rejects the large-scale transfer of population from the north-east of England to other areas as socially and economically undesirable; although there is nothing in the memorandum to indicate dissent from the view implicit in the Beveridge Report that greater mobility of labour generally is desirable, if not essential. The memorandum holds that the future policy should be to employ people in their own surroundings. The Group believes that the northeast of England has its own background and a tradition of virility and of independence which is an asset to the nation and should be preserved. Social security may, in fact, increasingly necessitate the adjustment of employment to the distribution of population.

Such considerations lead to the conclusion that the solution of the industrial problem of the north-east of England lies in the development in the area of a much greater variety of industries making highly developed products suitable for export as well as for the home market. Such a development would mitigate a permanent change in employment by heavy industry and provide a reserve of employment to meet fluctua. tions. In particular, further developments in the area of the processing of coal to oil, plastics, etc., are recommended, and the memorandum urges that whatever emerges as part of Great Britain's fuel policy from experimental work now in progress should be concentrated in this and other coal-producing regions. Again, certain parts of the area should be cleared of derelict buildings to encourage development, and any further capacity required for war production should be located in the area. After the War, an active policy of building factories in the area to make up for the effects of war development should be prosecuted, with the transfer of factories rather than labour.

All this, and the continuance of the measures adopted before the War to bring light industries to the north-east of England, involves a national policy for the location of industry, and the memorandum once more directs attention to the necessity for implementing the recommendations of the Barlow Commission. The reference to this question which Lord Woolton made in his recent statement shows that the Government is already giving some attention to the problem of structural unemployment, and Lord Woolton suggested that the Government might use the disposition of State factories to assist the creation of a diversity of industries in areas such as the northeast coast. Mr. Dalton had already broached the idea that such factories might become the nucleus of new trading estates, and it may be that the Government is giving more attention to the location of industry than has appeared in its pronouncements.

Other recommendations in this memorandum touching on the same question are the consideration of freight rates and their effect on the location of new industries, the provision of national finance for the local reorganization of housing and industry in certain areas such as part of south-west Durham, amendment of housing legislation to allow of more flexibility and a closer co-ordination with industrial policy and the provision of additional trading estate facilities in the area. Once again the multiplicity of local authorities, particularly on Tyneside, and the limitations of the rating system, with the consequent encouragement of sectional and parochial views, receive strong comment, and here again it is urged that the areas of local authorities should be re-drawn to give larger and more effective units. In this the memorandum is clearly alive to the importance of maintaining local interest, attracting industry to take a larger share of this form of public service, and giving the local authorities wider and more effective scope for cooperation with the industrial community as a whole ; its final recommendation is the formation of a local development organization to continue the study of these problems, to co-ordinate them and keep them before the attention of the Government, utilizing the experience of the pre-war North-East Development Board and subsequent experience.

The memorandum clearly fits into the pattern of post-war employment policies which was covered broadly by Lord Woolton's statement in the House of Lords on February 15. Like that statement, it visualizes the need for some measure of Government control at least during the first two of the three economic phases through which we must pass during the immediate post-war years, and of definite guidance if not control during the third phase. Once again it emphasizes the necessity for Government decision and the elaboration of a policy in regard to such matters as the location of industry, before either particular industries or regions can proceed to elaborate their own plans. Furthermore, any such plans must be related to a national policy and plan, and clear guidance must be given as to the principles on which national and regional plans are to be based. Only then, and when some real attention has been given to the way in which such developments will react on the position and resources of local authorities and their relation to the central Government, can a practical scheme and time-table of demobilization be worked out and explained to those concerned.

Lord Woolton's own statement was admittedly incomplete, for it disregarded the international aspects of employment policy, control of raw materials, trade and currency policy. None the less, the ground he covered, leaving out of account the Service ministries that will be concerned with demobilization, relates to policy which must come under at least six depart- 
ments - the Treasury, the Board of Trade, and the Ministries of Production, Supply, Aircraft Production and Labour, apart altogether from the authorities concerned with building and physical reconstruction. The impossibility of fitting departmental policy and measures together, without the prior and clear enunciation of the main lines and principles of policy at the centre, in a way that will solve the long-term employment problem, and permit a smooth transition from a war to a peace economy could scarcely be demonstrated better. Nor can even the essential task of educating public opinion as to what is involved proceed until policy has thus been enunciated.

The necessity for such publicity is well brought out in an able analysis of the whole question of demobilization and employment, which frankly faces the general question of the depressed areas, contained in a broadsheet (No. 217) recently issued by Political and Economic Planning. The problems which will confront us in remobilizing for peace are examined in the light of the experience of the War of 1914-18, and while the necessity of striking a balance between economic needs and the desires of service men is recognized, the imperative necessity of a publicity campaign, planned with all the vision and skill at the Government's command, to explain the why and how of policy, is equally stressed. No scheme will avoid all difficulties, but if the situation is fairly and simply explained to the millions of service men and war workers, it would do much to temper impatience and to curb over-sanguine expectations.

The preliminary analysis in the broadsheet follows the lines of Lord Woolton's statement. For several years the demand for man-power will far exceed the supply; quite apart from war requirements in the Far East, massive dammed-up demands for peacetime goods will place a heavy load on industry for some time to come. Inflation rather than general unemployment will be the danger. Social equity and economic order alike will require a system of priorities, and these must be carefully balanced to ensure that demands are in harmony with industrial capacity.

Dealing first with military demobilization and viewing it as a part of the vast business of reorientating the war economy, the broadsheet points out that military factors will determine the rate of discharge. With regard to the question whether the rate of discharge should be left simply to military considerations or further controlled by the availability of jobs, the broadsheet quotes with approval the official view that the rate should be governed solely by operational requirements. The principles governing the order of release are likely to give far more difficulty, and here the wisdom of public announcement by the military authorities at an early date of the general principles they propose to adopt, and the strict observance of the principles formulated, are of paramount importance. The first rational principle is that industry's needs should be paramount: the speed with which the wheels of peace-time industry can be restarted will depend in part on the availability of certain key men. Some enterprises will be unable to revive quickly unless they are able to obtain the services of skilled men now in the Armed
Forces. To make personal and family status the only test might quickly lead to chaos. Some account must be taken of the industrial background at home, though none the less policy must be affected by what service men will regard as fair.

The essential proposals of the report on demobilization issued by the Liberal Party Committee are in striking harmony with many of the views of $\mathrm{P} E \mathrm{P}$. The features of the Liberal Party's report are the emphasis placed on the need for speed in carrying out demobilization, and the insistence on the improvement of conditions of pay and service in the Armed Forces so that it may be possible to recruit without delay a professional army for the maintenance of order abroad. The report urges that it is the negation of both democracy and justice to retain the principle of compulsion in relation to military service merely to avoid the introduction of adequate scales of pay.

Plans for re-settlement in civil life are of capital importance in any demobilization scheme, and this report and the broadsheet both stress the necessity for opportunities for re-training and education. The report would make the continued receipt of pay and allowances, and certainly of unemployment benefit, after the first three months, conditional on attendance at training centres by those who had been unable to obtain civilian employment, while the broadsheet urges a serious effort to mobilize as many teachers as possible for this purpose. The Government plans are welcomed, especially the appointment of the strong committee under Lord Hankey to advise the Appointments Department of the Ministry of Labour. The debates on the Reinstatement in Employment Bill have made it plain that reinstatement is only part of a bigger problem. The crux of the matter is to ensure employment, and the broadsheet, in discussing what may be termed the reception end, suggests that the employment exchanges must be made both more efficient and more acceptable to employers and employees alike than they were before the War. It is also suggested that the exchanges might draw on Army experience with intelligence and aptitude tests for fitting the right man to the right job, and take over some of the trained Army personnel. Records which have been accumulated by the Services should be made available to the exchanges, so that they have information not only about a man's technical training and service experience but also about his general aptitudes.

Turning then to the question of industrial employment, the P E P broadsheet has no hesitation in assum. ing that a high demand for labour will continue. Apart from the military demands for the War in the Far East, production in general may not slacken nearly so much as many people think ; there will be a vast demand waiting to be satisfied in the civilian field, and there will be keen competition to utilize any resources which may be released from the war effort. Export, for example, must rank as a high priority. It is of the first importance that Britain should not let domestic demands so swamp productive capacity that export markets are lost by default. Consumers will also wish to make good the accumulated deficiencies of war-time, and there will be the more 
serious deficiencies in the nation's capital equipment to make good, notably in building; finally, Britain will have to bear her share of the cost of relief for the great areas of the world which have been devastated or impoverished by the Nazis or the Japanese.

The great problem in the view of $\mathbf{P} \mathbf{E}$ will be how to secure enough labour for the jobs that will need doing--for continued military production, for exports, for housing, for the manufacture of consumers' goods for relief. Accordingly, it will be essential for the Ministry of Labour to retain its powers under the Essential Work Orders. As a consequence of the prevailing shortage, the labour factur will continue to be of high importance in the general economic strategy, and the position of the Ministry of Labour as pivotal as it has become in the later stages of the War.

Two provisos are made to the general proposition that there will be a shortage of labour for some years after the end of hostilities in Europe. First, as already indicated, some temporary unemployment due to the transition from one type of production to another, and from war to peace production, is inevitable. Secondly, employment opportunities will not necessarily be distributed in accordance with the supply of labour. There may be pockets of unemployment, and the Northern Industrial Group in its memorandum directs attention to this outstanding danger which may threaten other areas besides the northeast coast of England.

P E P urges that it should be one of the great aims of Government policy to encourage industrial development in these areas. The end of the War should provide a great opportunity to establish in the former Depressed Areas new enterprises giving a better balance between foreign and home markets, and between light and heavy industries. The Government's many powerful instruments of control place it in a strong position to prevent local unemployment either in the short or in the long run. As the chief customer for most of the country's industry, the Government will possess in the process of terminating its contracts a strong lever which could be used to minimize or prevent local unemployment. The dis. position of plant and equipment owned by the State and the power to license materials could all be used to prevent local unemployment, for example, by implementing trading estates, new centres of light industry and developing new processes and raw materials, as the president of the Board of Trade has already indicated.

Despite the complexity of the problems involved in military demobilization and industrial re-adjustment, there is therefore no reason for pessimism as to the employment situation in Great Britain ; there should be little danger of general, though there will be some danger of local, unemployment. The process of adjustment can, however, only be made tolerable by planning, and by the retention of some at least of the measures of war-time control. If that is to succeed, the reasons for planning and control must be made plain to all, and their purpose clearly and honestly explained. That is as essential as it is that the Government should make its decisions and announce its central policy as early as possible, so that regional and local action is possible in harmony with the national plan, and as large a measure of initiative and freedom afforded to local enterprise as is consisitent with orderly transition from war to peace.

\section{JUDGMENT ON PLANNING}

\section{$T \vee A$}

Adventure in Planning. By Prof. Julian Huxley. Pp. 142. (Cheam: Architectural Press, Ltd., 1943.) 8s. $6 d$.

THE Tennessee Valley Authority has now been established for ten years, and the experience of a full decade renders possible an attempt to assess its achievements and their significance, both in relation to the problems of regional planning in Great Britain and to the no less difficult range of administrative problems involved in public control and the relations between local and central government. In giving us the first detailed account published in Great Britain of this achievement, Dr. Huxley provides an admirable complement to Prof. C. Herman Pritchett's "The Tennessee Valley Authority : a Study in Public Alministration", copies of which only now appear to have reached this country, although it was published in the United States in 1942.

Prof. Pritchett's book, as its sub-title indicates, is in the sequence of Prof. R. E. Cushman's study "The Independent Regulatory Commissions", from which consideration of the Tennessee Valley Authority was expressly excluded. It is concerned essentially with the political and administrative problems of the venture and makes a striking appendix to the report of the President's Committee on Administrative Management. Dr. Huxley, on the other hand, while not ignoring these aspects, places his main stress on the social and broader technical aspects of what he rightly terms an experiment or adventure in planning. His able presentation of the whole range of problems, and his skilful and lucid delineation of the fundamental questions or principles involved, coupled with the admirable photographs with which the book is illustrated and a good bibliography, should make his book as welcome to the serious student as to the general reader.

For the scientific worker, this account of the use of the scientific method of research, survey and experiment in dealing with great and complex social and economic problems is of special interest. Even those who have some knowledge of the achievements of the Tennessee Valley Authority in regard to power supply and to soil conservation may well be surprised at the picture Dr. Huxley gives of the effects of this great experiment on agriculture, health, labour, education, architecture and design. From the outset, the Authority has realized the enormous potential value of its reservoirs for recreation, and from this has proceeded to plan for the same development of all aspects of recreation in the Valley. No section of Dr. Huxley's book is more suggestive at the present time than that in which he describes the work of the Authority in regard to parks and wild life, and it deserves the close attention of all those concerned with present proposals for nature reserves or national parks in Britain.

Continuous research and survey are the essence of any large-scale planning, but many scientific workers will learn for the first time in these pages of 